\title{
Migration to Europe and its demographic background
}

\begin{abstract}
Marcell Farkas Analyses of available data on international mi-
University of Pécs, gration are becoming increasingly important in Doctoral School of Earth Sciences, demographic projections year after year in the

Hungary age of human mobility. As Europe experienced

E-mail: an unprecedented mass inflow of refugees and foldfm92@gamma.ttk.pte.hu

Zoltán Dövényi

University of Pécs,

Doctoral School of Earth Sciences,

Hungary

E-mail:

dovenyiz@gamma.ttk.pte.hu

War, research on the demographic trends of

refugees' main countries of origin has also be-

come important. To provide relevant information for this debate, the paper identifies the demographic tendencies of the six main countries of origin in Asia and Africa - Syria, Iraq, Afghanistan, Somalia, Nigeria, and Eritrea - for the EU's 28 member states by the number of asylum applicants between 2008 and 2016. First, basic demographic indicators (e.g. total fertility rate [TFR] and life expectancy) of these six countries are analysed. Then the changing share of the young (15-19) and retiring (55-59) male age groups - referred to as the demo-

Keywords: graphic war index (DWI) - in these six counforced migration, tries and major regions of the world are comrefugee, pared. Finally, by examining the spatial distri-

European Union, bution of the global refugee population and demography, armed conflicts, the research aims to reveal the armed conflict relevance of the DWI.
\end{abstract}

\section{Introduction}

Initially, population projections focused only on a closed population, which implies that there is no inflow or outflow of immigrants in a certain state. Migration was 'not yet on a large enough scale to merit international intervention' until around 1980. Before that period, governments aimed to convince immigrants not to stay for a long period through strict legislation on migration, rather than understanding these flows and demographic consequences thereof (Booth 1982).

From the late 1970s, the growing impact of human mobility on population dynamics increased the importance of analysing migration data for demographic pro-

Regional Statistics, Vol. 8. No. 1. 2018: 29-48; DOI: 10.15196/RS080103 
jections (Kelly 2000). Since then, migration has become an integrated part of social demography, which tries to explain the impacts and consequences of various demographic indicators such as the dynamics of age and sex structure as well as fertility, mortality, and net migration rates on a given population. Therefore, social demography also employs the theories of other social sciences like sociology, macro and microeconomics, political science, and anthropology. The role of political science in demography is the analysis of the changing legal background and government policies underlying immigration (Borjas 1989, Kelly 2000, L. Rédei 2006).

The challenges of providing accurate population projections include collecting relevant and integrated statistical data on immigration and emigration trends, and the incoherent definitions of what can be considered migration. This is because a change of residence can be permanent, temporary, or circular. Temporary stays are mostly business or tourist trips or short-term studies, which can be extended to a long-term stay through legal (e.g. obtaining a residence permit) or illegal (e.g. overstaying a visa) means. According to the definition by the United Nations, a minimum stay of one year is required for the recognition of a person as an international migrant, although it is not always followed in the national legislation of all countries (Ravenstein 1889, Lee 1966, Kraly-Gnanasekaran 1987, Zolberg 1989, Willekens 1994, Kelly 2000). However, the 1951 Refugee Convention does not fit this definition, as the status can be given within a year after fulfilling all criteria ${ }^{1}$ mentioned in the Convention during the asylum decision process. This means that refugees are counted as international migrants regardless of the length of their stay in the country of asylum. The main demographic difference between these involuntary or forced movements and economic migration is that all age groups and families are affected by armed conflicts; thus, not only young men (who are the majority of most firstgeneration economic migrants) are seeking safety. A significant number of refugees also consider these movements as a temporary change of residence, even if they reside in the country of asylum for years or decades, while economic migrants are more likely to be involved in long-term social inclusion, because their immigration is often based on a long-term or permanent decision (Borjas 1989, Kelly 2000).

Reflecting the main trends in international migration, this research focuses on involuntary migration considering that claiming for asylum is an important but less investigated way of entering the European Union (EU) for third country nationals.

This focus is on the overall number of asylum applicants in the EU by country of origin (between 2008 and 2016) $)^{2}$, not on the number of refugees. This is because a significant number of asylum seekers leave their reception centres, and in many

${ }^{1}$ According to the most widely accepted definition in the 1951 UN Convention and 1967 Protocol, the three main criteria for the recognition of someone as a refugee are the following: those who have left their country of origin (meaning that internally displaced people [IDPs] are not considered refugees), because of the fear of being prosecuted for racial or religious reasons or being a member of a social or political group (not because of economic or environmental reasons), and are unable or not willing to accept the protection of that country because of their fear (UNHCR).

${ }^{2}$ No sufficient and coherent Eurostat data are available for all EU member states prior to 2008.

Regional Statistics, Vol. 8. No. 1. 2018: 29-48; DOI: 10.15196/RS080103 
cases, the given member state without official documents while their asylum application process is still ongoing. Since they often remain invisible to the state authorities, their movements cannot be tracked within the Schengen Area. However, their economic impact - especially on the black market - is significant, for example in Almeria (Spain) or Sicily (Italy). On the other hand, many are given other forms of humanitarian status. For example, in Hungary, subsidiary or temporary protection is not counted in the overall number of recognised refugees. These forms of humanitarian statuses and given rights vary between the member states. In addition, some illegal border-crossers detected and registered by European border guards may not apply for asylum, but reside in the EU (GMDAC 2018).

Previous research focused on internal demographic pressure from the viewpoint of host countries, analysing the demographic trends of immigrants. However, this research aims to identify and analyse the tendencies of the main countries of origin for asylum applicants from Asia (Syria, Iraq, and Afghanistan) and Africa (Somalia, Nigeria, and Eritrea) to measure the external pressure on the EU.

Since both high and low variant scenarios of population projections are equally possible, data for a medium variant projection are used as an average. Forced migration flows are highly related to armed conflicts; therefore, the relevance of the DWI in the main sending countries is examined. This ratio tries to explain the risk of violence stemming from fewer resources and job opportunities (Heinsohn 2003, 2017a, 2017b).

\section{Migration to Europe: Refugees and asylum seekers}

Before exploring the demographic characteristics of the main countries of origin, changes in the trends of refugee and asylum seeker migration in the past decades from the perspective of Europe must be identified.

According to the United Nations High Commissioner for Refugees (UNHCR), approximately 22.5 million recognised refugees (including 5.3 million Palestinian refugees under the mandate of the United Nationals Relief and Works Agency for Palestine Refugees in the Near East) and 2.8 million asylum seekers were living worldwide in 2016. This is a relatively stable and small proportion of the 258 million international migrants, the number of which increased from 173 million in 2000 (Ekéné Zamárdi-Dövényi 2010, L. Rédei 2014, Abel-Sander 2014, United Nations 2017). Furthermore, the overall number of IDPs was around 40.3 million, meaning that more than 65.6 million people have been forcibly displaced from their homes or countries of origin worldwide, which has led to an unprecedented crisis. This is significant growth in barely two decades from 33.9 million people in 1997. The globally displaced population increased rapidly after the outbreak of the Syrian civil war in 2011, but other escalating conflicts in Iraq, Yemen, the Democratic Republic of Congo, Sudan, South Sudan, and the Central African Republic have also played a significant role in today's global refugee crisis (UNHCR 2017).

Regional Statistics, Vol. 8. No. 1. 2018: 29-48; DOI: 10.15196/RS080103 
As mentioned, it is more effective to study the number of asylum applicants rather than refugees because of the special trends of forced migration in the EU to measure each origin country's impact on migratory tendencies in the last decade.

Between 2008 and 2016, more than 4.9 million people were seeking asylum in the EU member states combined, of which more than half $(2.5$ million people or 51\%) arrived in 2015 and 2016. In addition to almost 1 million forcibly displaced Syrians, there were more than 0.5 million Afghani asylum seekers and hundreds of thousands of people from Iraq, Russia, Pakistan, Kosovo, Serbia, Nigeria, Eritrea, Somalia, Albania, and Iran. Registered applications from these country nationals vary between 378,000 and 141,000 (Kocsis et al. 2016, Eurostat). (See Figure 1.)

Figure 1

\section{Number of asylum applications in the EU, by main countries of origin}

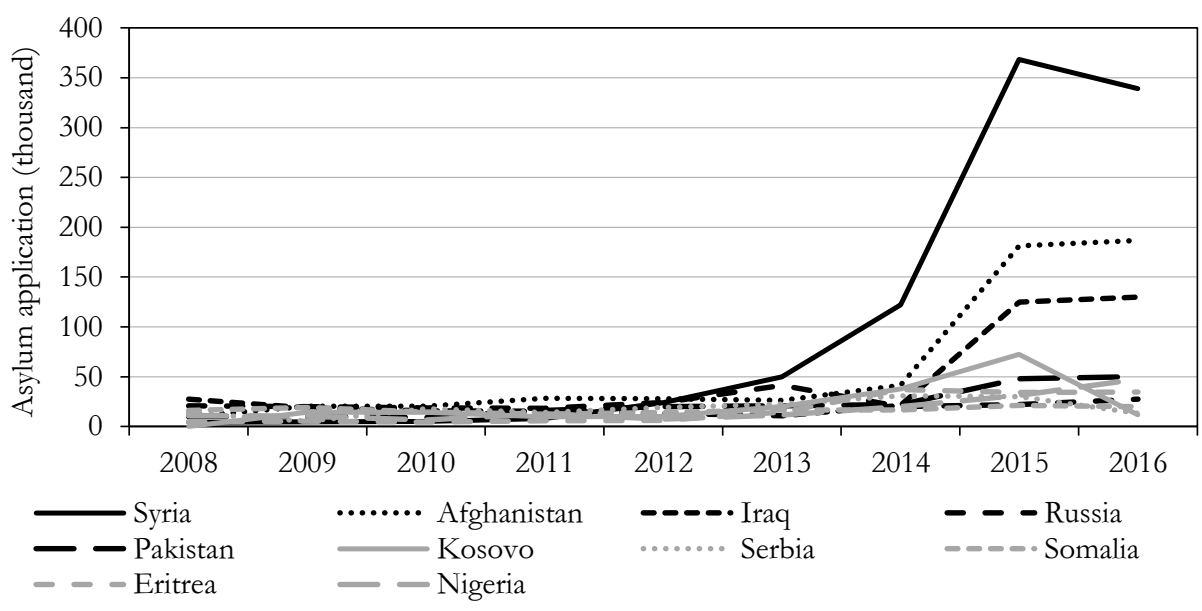

Source: Own calculation based on Eurostat data

Figure 1 shows that there was no major inflow of asylum seekers prior to 2013. After that, Syrian, Afghani, and Iraqi citizens began moving into Europe through Turkey on the Western Balkans migratory route in large numbers, surpassing 100,000 people each year. There was also a significant outflow from Kosovo through Serbia to Hungary ${ }^{3}$ in the beginning of 2015, followed by increased movement from Pakistan and Nigeria. Except for Kosovo, these main countries of origin have struggled with increasing political instability and escalating civil wars or other forms of armed conflicts for years or decades (in the case of Afghanistan or Pakistan) (Eurostat).

\footnotetext{
${ }^{3}$ On their way to Austria and Germany, thousands of these applicants stayed in the main railway stations in Budapest, Hungary. This led to the start of a political debate on immigration in Hungary and the decision to erect a border fence on Hungary's borders with Serbia and Croatia to manage the mass inflow of asylum seekers (Pap-Reményi 2017). Meanwhile, the inflow of regular economic migrants stayed stable in Hungary causing the political debate to focus mostly on refugees and asylum seekers at this time (Kincses 2015).
}

Regional Statistics, Vol. 8. No. 1. 2018: 29-48; DOI: 10.15196/RS080103 
Before 2014, Russian, Afghani, and Somali asylum seekers mostly used the migratory routes to Europe. Since then, military operations against the Islamic State (IS) and other militant groups in Syria and Iraq, as well as the deepening instability in Afghanistan, have led to an unprecedented refugee crisis in the Middle East (predominantly in Turkey, Lebanon, and Jordan) and the EU (mainly in Germany and Sweden) (Eurostat). (See the table.)

The five main countries of origin of EU's asylum applicants*

\begin{tabular}{|c|c|c|c|c|c|c|c|c|}
\hline 2008 & 2009 & 2010 & 2011 & 2012 & 2013 & 2014 & 2015 & 2016 \\
\hline Iraq & Afghan. & Afghan. & Afghan. & Afghan. & Syria & Syria & Syria & Syria \\
\hline Russia & Russia & Russia & Russia & Russia & Russia & Afghan. & Afghan. & Afghan. \\
\hline Somalia & Somalia & Somalia & Pakistan & Syria & Afghan. & Kosovo & Iraq & Iraq \\
\hline Serbia & Iraq & Iraq & Iraq & Pakistan & Serbia & Eritrea & Kosovo & Pakistan \\
\hline Nigeria & Kosovo & Kosovo & Serbia & Serbia & Pakistan & Serbia & Albania & Nigeria \\
\hline
\end{tabular}

* Data for 2017 will be available later in 2018. However, between January and November 2017, the highest number of those crossing the border illegally registered at the external borders of the EU were from Nigeria, Syria, Cote d'Ivoire, Guinea, and Iraq (Frontex).

Note: Afghan. - Afghanistan. Asian countries are indicated in green, European countries in blue and African countries in brown.

Source: Own elaboration based on Eurostat data.

This study analyses the demographic trends of the six main countries of origin for asylum applicants from Asia (Syria, Iraq, and Afghanistan) and Africa (Nigeria, Somalia, and Eritrea). Furthermore, differences between major regions in terms of the changing share of the young (15-19) and retiring (55-59) male age groups are studied. The main countries of origin for European asylum applicants (Russia, Kosovo, Serbia) are not analysed, because of their low recognition rate and the fact that the demographic characteristics of these countries is similar to the European average.

\section{Demographic trends of the main countries of origin}

Before analysing specific demographic indicators, it is important to know how the projected population of these six countries might change by 2100. As Figure 2 shows, it is expected that these countries will have a much larger and younger population. The number of inhabitants in Syria and Afghanistan are projected to double, and the populations of Eritrea and Iraq are expected to triple. However, the populations of Somalia and Nigeria will likely increase five times by the end of the century (United Nations). As such, Nigeria is projected to be the third most populated country in the World behind India and China with almost 1 billion inhabitants, making it not only the 'giant' of Africa, but also of the world in terms of population.

Regional Statistics, Vol. 8. No. 1. 2018: 29-48; DOI: 10.15196/RS080103 
Among others, the country's higher rate of urbanisation due to internal migration from arid rural areas, the growing size of the young middle-class population and the development of the IT and communication sector will likely increase the interstate and intercontinental mobility of Nigerians and middle-aged or young inhabitants from other countries of the global South. In parallel with these increasing populations, the impact of violent non-state actors on refugee migration is becoming more significant (Kasakoff-Adams 1995).

Figure 2

\section{Previous and projected population in the main countries of origin of EU's asylum applicants}

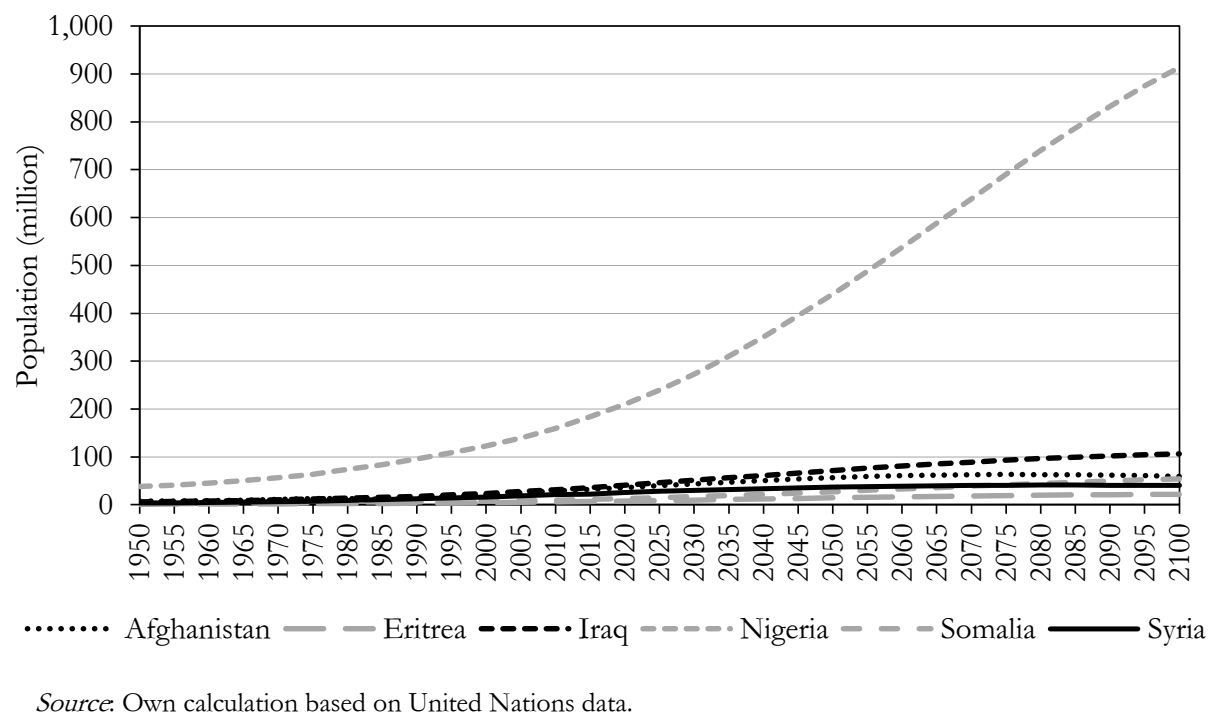

Currently, these countries of origin have a TFR much higher than the world average (varying between 3.7 and 6.1), except for Syria. Syria was expected to reach this average around 2020, but this seems unrealistic after the outbreak of the civil war in 2011. The rates for the other countries might also decrease, and in the fourth period of the demographic transition, may reach the world average later - between 2035 (Afghanistan) and 2060 (Eritrea, Iraq) - or remain above it, even at the end of the century (Somalia, Nigeria) (United Nations). (See Figure 3.) All these countries house a very young population with a median age lower than 25 years (CIA). This implies that a need for new jobs in the major cities of these countries will constantly increase, as they struggle with higher rates of population growth because of rising internal migration from rural areas. The lack in new positions due to this population growth could increase pressure on people to seek better life opportunities outside their countries.

Regional Statistics, Vol. 8. No. 1. 2018: 29-48; DOI: 10.15196/RS080103 
Total fertility rate in the main countries of origin of EU's asylum applicants

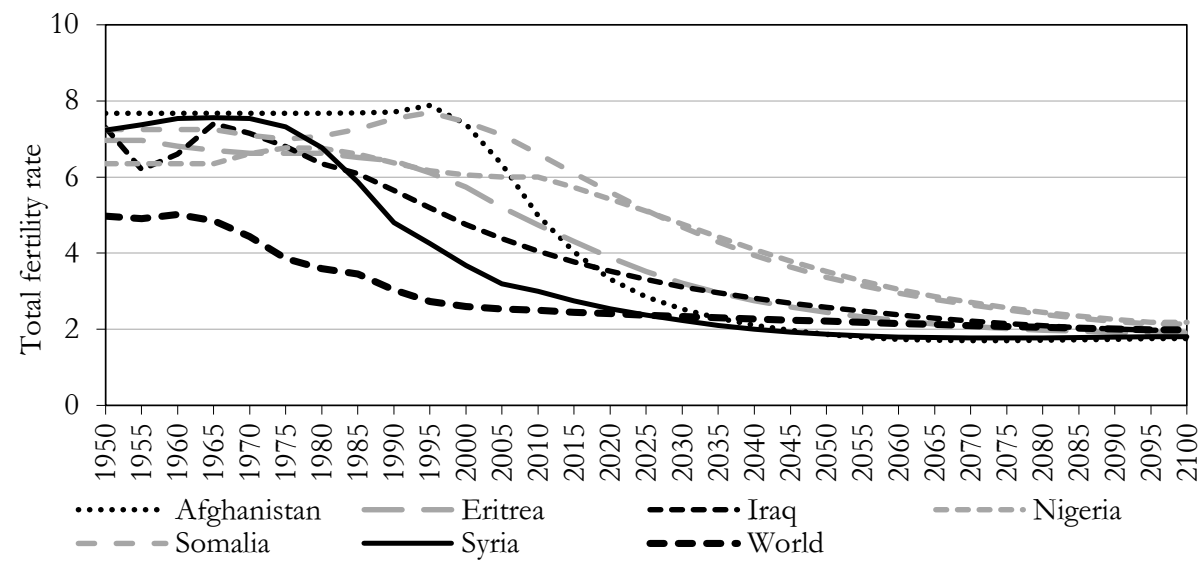

Source: Own calculation based on United Nations data.

Furthermore, the life expectancy of the main countries of origin, as in other countries worldwide, will increase in parallel with the world average from 65 to 80 years by the late years of the century. The life expectancy in Syria has significantly dropped since the start of the civil war. Because of the harsh living conditions, the medium variant data provided above is likely high, and a low variant scenario may be more realistic for life expectancy (United Nations). (See Figure 4). However, this suggests that more people may remain in the job market and work until their late 50 s or early 60 s.

Figure 4

Life expectancy in the main countries of origin of EU's asylum applicants

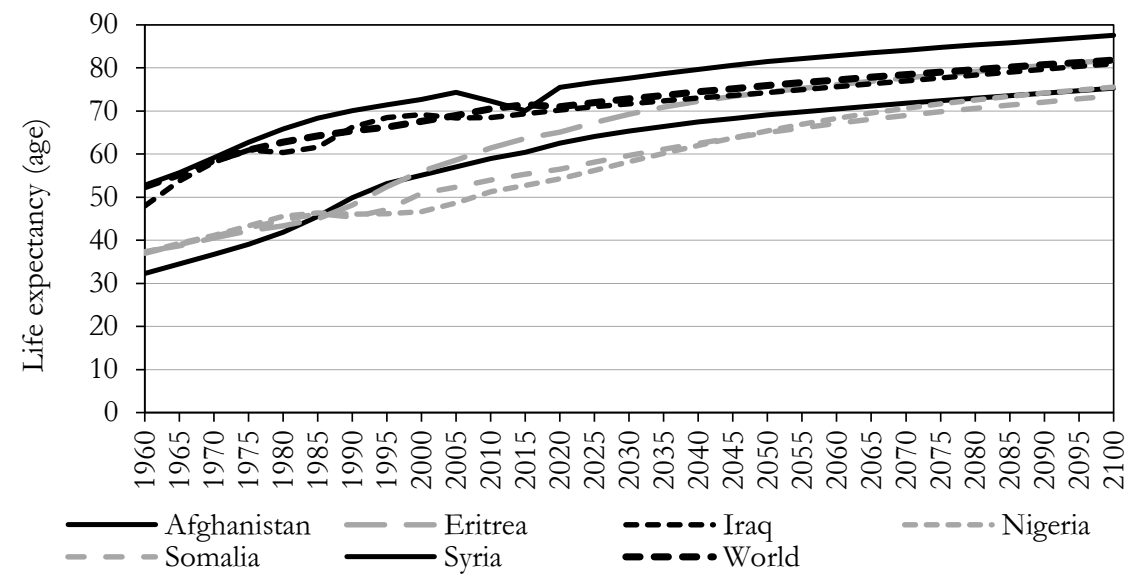

Source: Own calculation based on United Nations data.

Regional Statistics, Vol. 8. No. 1. 2018: 29-48; DOI: 10.15196/RS080103 
Considering this and a lower mortality than birth rate, it is expected that the populations of these countries at least will double before peaking, as mentioned.

\section{The demographic war index and relevance thereof}

Many aspects of the demography behind conflicts remain under-examined. In this regard, Brunborg-Tabeau (2005), Brunborg-Urdal (2005) highlight five important research fields: the intersection of demography and conflict studies, demographic indicators and factors and their role in conflict, impact of violent militant activities on demography, methodology and data to be used, and coherence of the demography behind special cases ranging from gang violence through terrorism to genocides. This paper connects previous research (Choucri 1974, Cincotta-EngelmanAnastasion 2003, Randall 2005) to analyse the share of certain age groups in the total population to emphasise the impact of demographic pressure on the social risk of armed conflict. The dependency ratio is often used to measure the pressure on a productive population. However, this paper underlines the demographic role of these to enter the job market, as they are the young population who would likely protest economic and political problems, which could lead to increased violence.

The DWI ${ }^{4}$ was created to analyse the possibility of increased violence for fewer resources and jobs per capita while comparing the rate of the younger (15-19) age group of males entering the job market with those (aged 55-59) leaving it in the same year, in a specific year and state. For example, a rate of 2.5 indicates that 2,500 young men are willing to get a job for every 1,000 men retiring that year. A rate below 1.0 indicates that countries with an ageing population are in need of a labour force, while a rate higher than 2.5 shows a higher risk of social and economic crisis, which can lead to political, religious, and ethnic conflicts (HeinsohnSteiger 1977, 1979a, 1979b, 1980, Heinsohn 2003, 2017a, 2017b). According to the 'Youth Bulges Theory', a 3.0 value is considered critical. Just as in the previously cited research, the rate of 2.5 is used in this paper, as it can already be considered demanding because of the significant growth in population expressed in absolute numbers (Urdal 2005, 2006, Nordås-Davenport 2013).

Another reason why DWI is used in this research is that the issue of global refugee migration and forced displacement is highly related to armed conflicts for various political, ethnic, religious, etc. purposes. The research reported in this paper aimed to measure the relevance of the theory of demographic pressure on the labour market and social system using the DWI from a geographic perspective, analysing both the spatial distribution of displaced populations and armed conflicts. Economic indicators and other changes in economic conditions cannot be projected as accurately as the population dynamics in a certain country. The lack of, or extra

\footnotetext{
${ }^{4}$ The authors considered calling it the demographic crisis/conflict index or social tension index, but the original term is used in this paper.
}

Regional Statistics, Vol. 8. No. 1. 2018: 29-48; DOI: 10.15196/RS080103 
foreign direct investment, local company competitiveness, stronger role of ruling governments, environmental degradation, etc. can also worsen or improve circumstances (Collier-Hoeffler 1998, Collier 2000). Therefore, the results presented in this section are representative of a theoretical approach.

Regarding continental differences in the DWI, these major regions already have a rate lower than 2.5, except for Africa with a value of 4.4 (Heinsohn 2003, 2017a, 2017b). (See Figure 5.) This means that considering only demographic factors, Africa will likely be the most affected region in the case of armed conflicts. This statement is strengthened by the fact that people forced to leave their homes mostly reside in their own country in another region or along the border zone of neighbouring countries. However, significant population growth will still increase the number of those seeking refuge in countries further away. This will retain the constant pressure on Europe from the waves of migration due to economic, political or social reasons.

In 2017, 88 countries housed approximately 1.7 billion inhabitants and had an index higher than 2.5, while in 2030, 66 countries will have a total population of 2.2 billion and an index above this rate (Heinsohn 2003, 2017a, 2017b).

Figure 5

Development of the demographic war index by continent

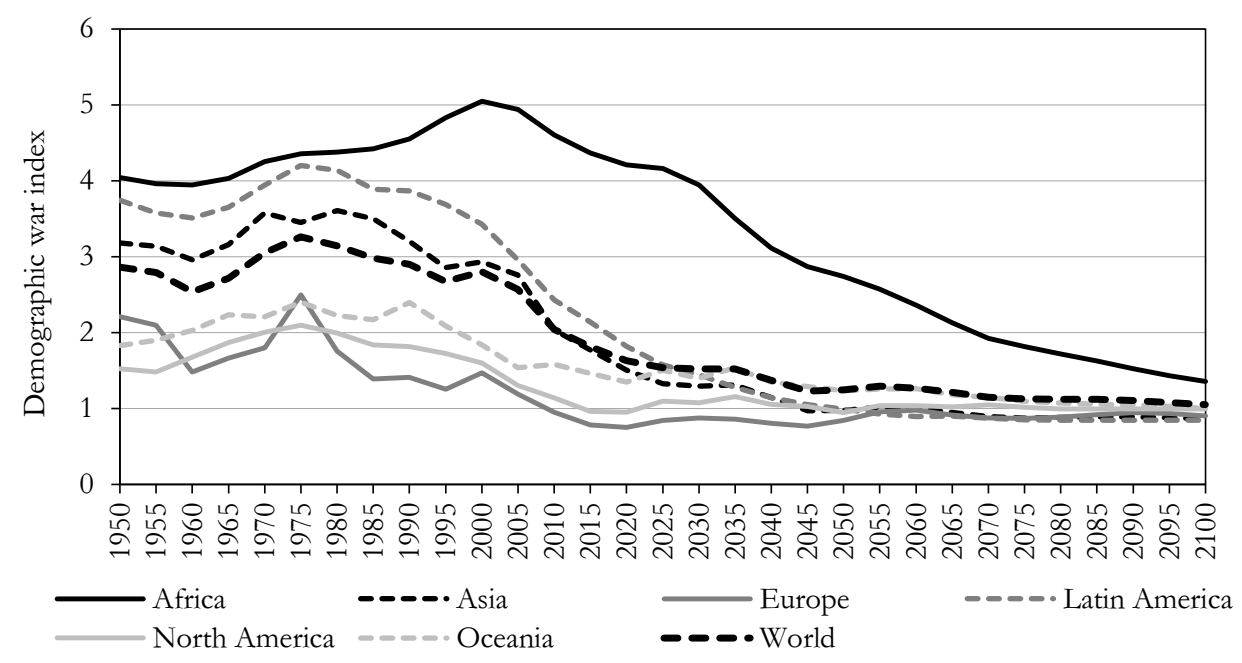

Source: Own calculation based on Heinsohn (2003, 2017a, 2017b) and United Nations data.

A further examination of regional differences reveals constantly changing differences between major regions. In 1950, developed Western and Northern European as well as North American countries along with Italy, Hungary, Australia, New Zealand, Argentina, and Uruguay were below the DWI value of 2.5. Only a few countries had a very high rating (Niger, Turkey, Paraguay), indicating that the

Regional Statistics, Vol. 8. No. 1. 2018: 29-48; DOI: 10.15196/RS080103 
demographic transition was in an early stage in the developing world that year and the risk of violence caused by demographic issues was moderate (TabutinSchoumaker 2004, Tabutin-Schoumaker et al. 2005, Heinsohn 2003, 2017a, 2017b). (See Figure 6.)

Regional differences in the demographic war index, 1950

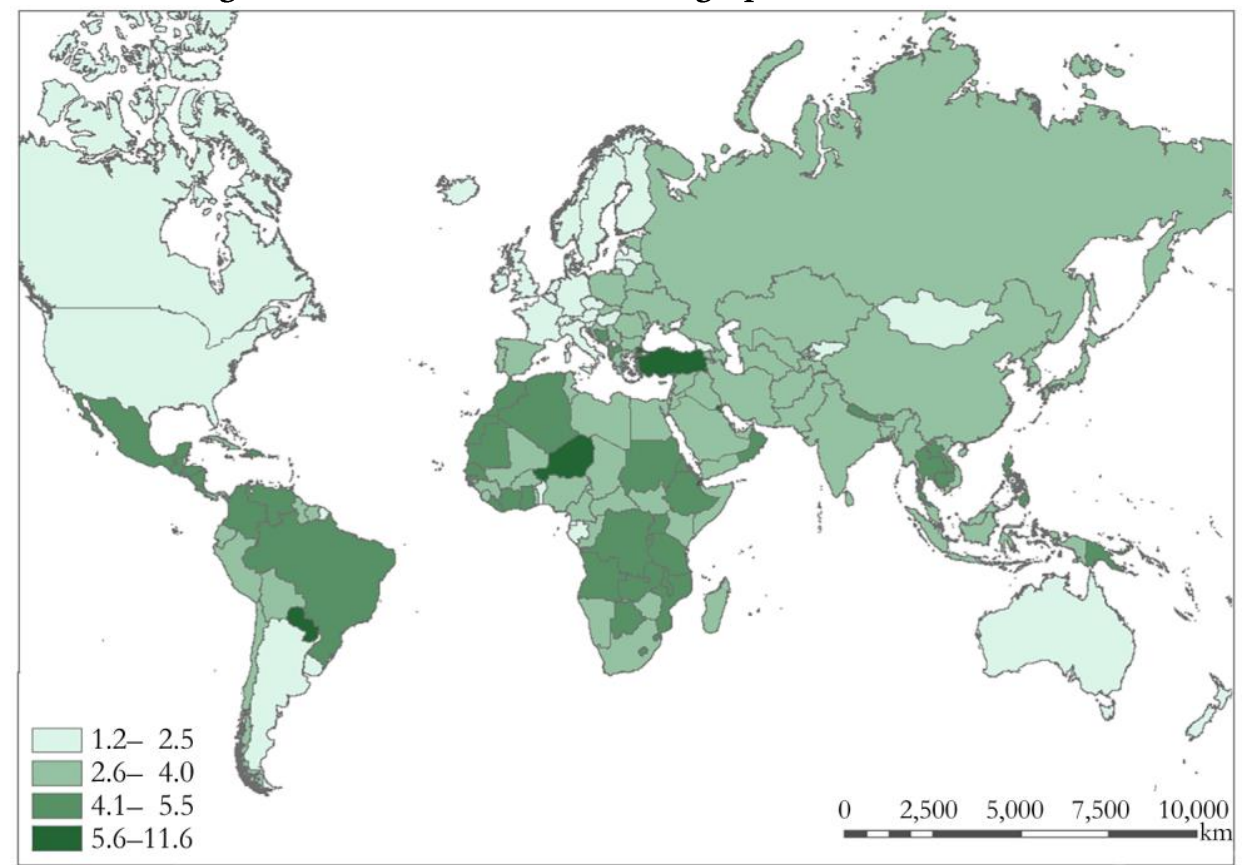

Source. Elaboration of Simon, B. and Farkas, M., based on Heinsohn (2003, 2017a, 2017b) and United Nations data.

These differences became more visible by 2010: almost all of Africa and some Middle Eastern (Syria, Iraq, Yemen), Southern and Southeast Asian (Afghanistan, Pakistan and Bangladesh), and Central American countries had the highest values, while large parts of Europe and Japan decreased below the rate of 1.0, indicating a shrinking population. The number of countries below the critical rate of 2.5 increased as Eastern and Southern Asian (including China and Indonesia) and South American countries (including Brazil) reached that value (Lesthaeghe 2010, N. Rózsa 2012, Heinsohn 2003, 2017a, 2017b, Demény 2016). (See Figure 7.) 
Regional differences in the demographic war index, 2010

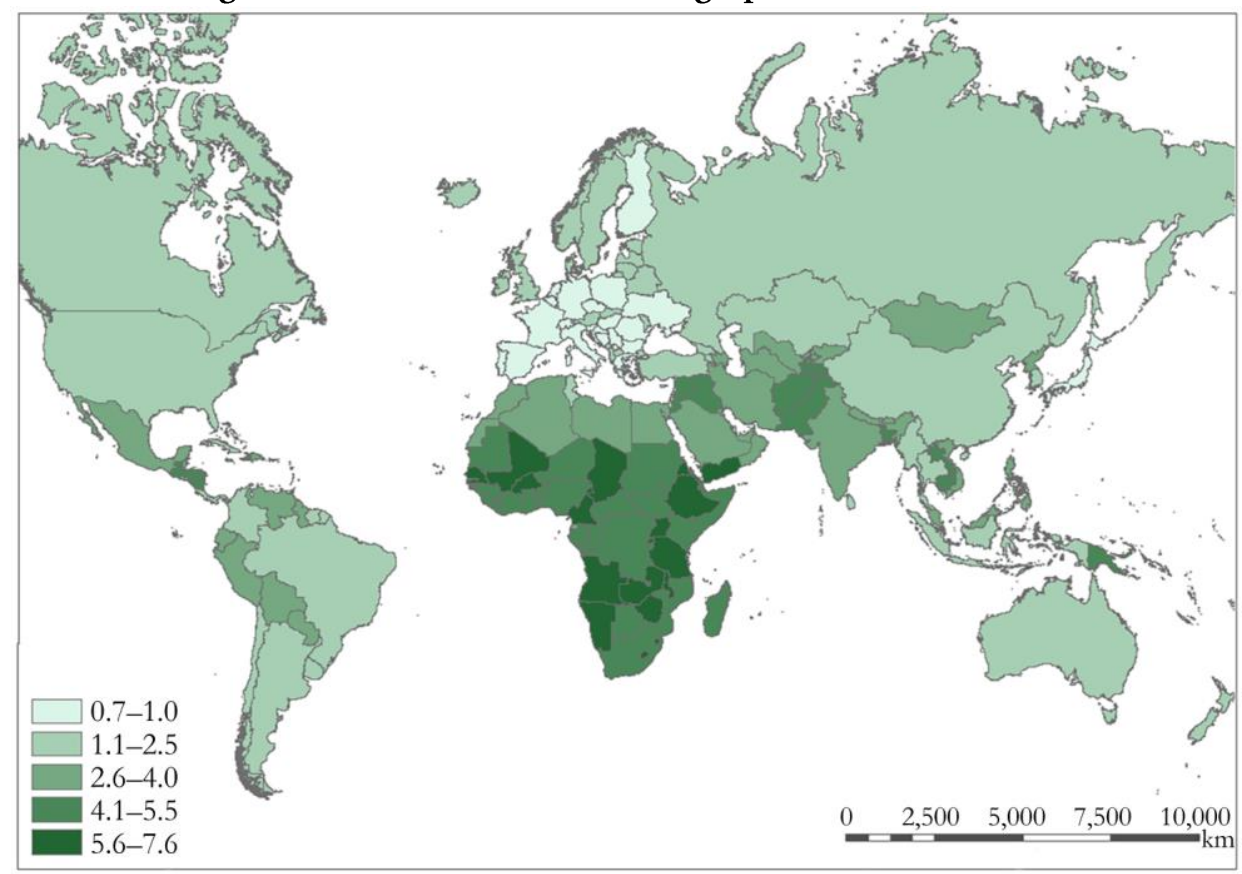

Source. Elaboration of Simon, B. and Farkas, M., based on Heinsohn (2003, 2017a, 2017b) and United Nations data.

Furthermore, notable or significant changes are expected to occur until 2050. Africa will still have the highest values (with Morocco and Tunisia the exceptions), as almost all countries (except for Iraq) with a value higher than 2.5 will be located on that continent. The differences between generations will be most significant in Nigeria, Somalia, Mali, and Angola. Regions with a shrinking population - including already China, Brazil, the United States, etc. - will be more widespread as the number of developed countries grows (Heinsohn 2003, 2017a, 2017b, Tarrósy 2017). (See Figure 8.)

Regional Statistics, Vol. 8. No. 1. 2018: 29-48; DOI: 10.15196/RS080103 
Projected regional differences in the demographic war index, 2050

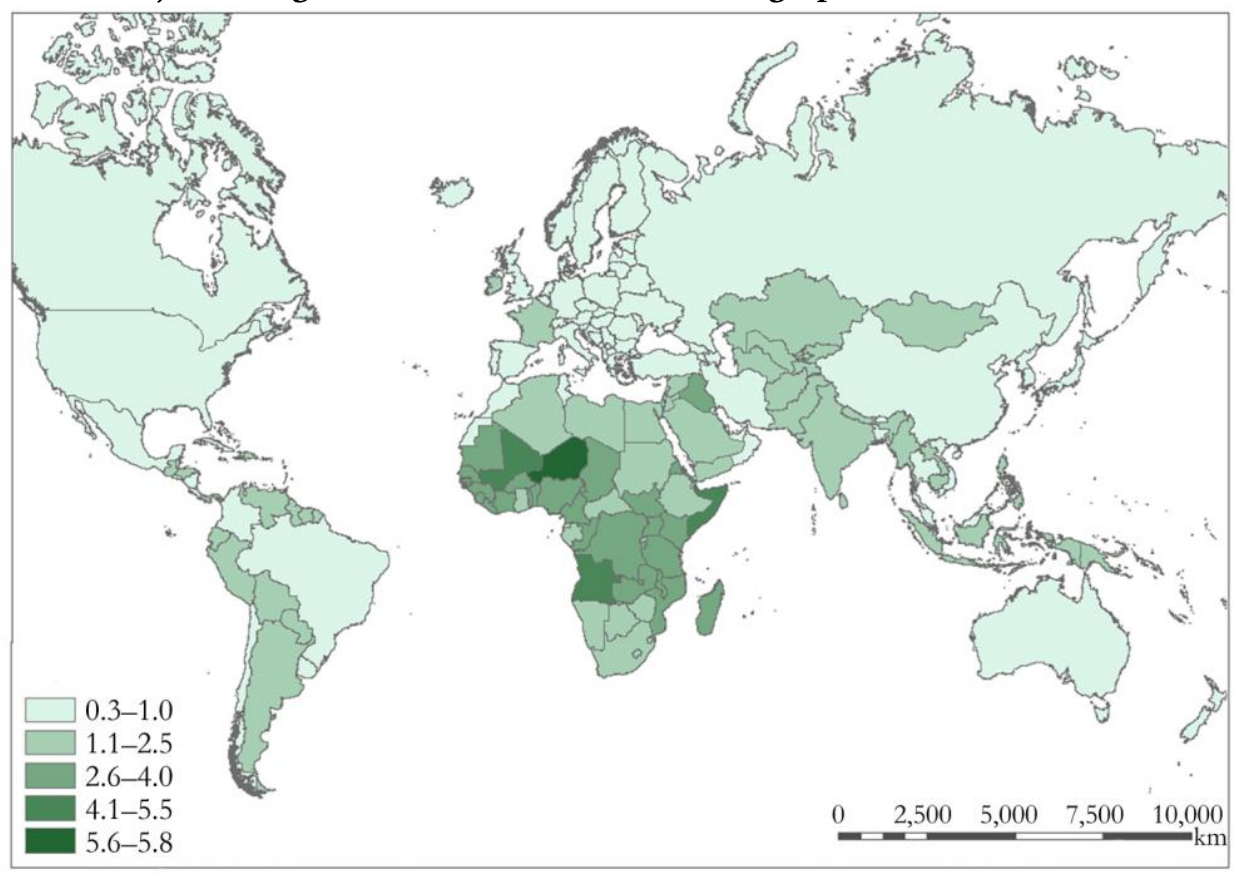

Source: Elaboration of Simon, B. and Farkas, M., based on Heinsohn (2003, 2017a, 2017b) and United Nations data.

However, no major difference is projected by the United Nations for the end of the century. A stable demographic makeup of the global population is expected on average, which might indicate a significantly shrinking population in developed regions (Heinsohn 2003, 2017a, 2017b). (See Figure 9.) Considering the natural increase in the birth rate after armed conflicts, the high variant scenario could represent a more accurate projection. However, these differences may fluctuate because of significant social, political or economic changes that cannot be predicted now. 
Figure 9

Projected regional differences in the demographic war index, 2100

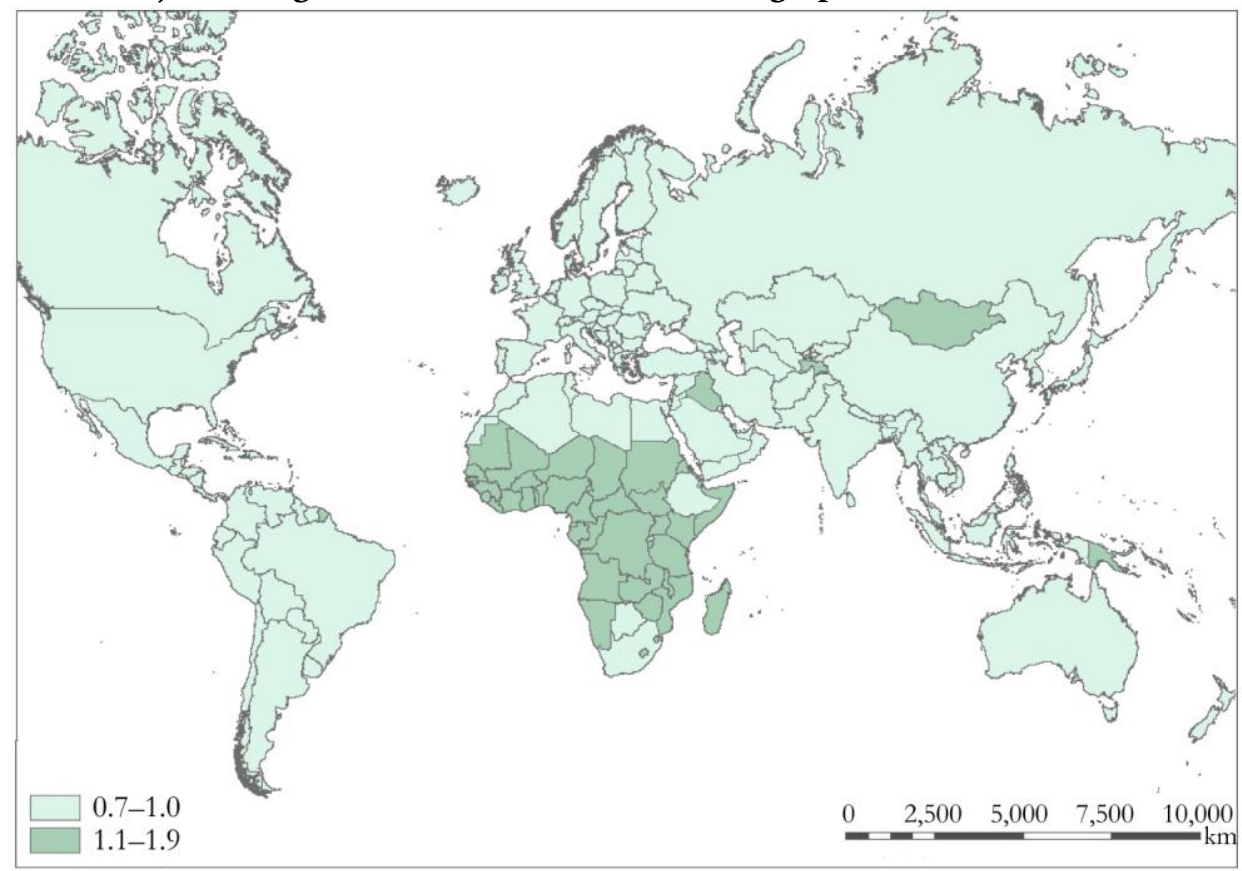

Source: Elaboration of Simon, B. and Farkas, M., based on Heinsohn (2003, 2017a, 2017b) and United Nations data.

Between 2025 and 2035, it is expected that the DWI value will decrease yearly in all six main countries of origin, scoring the mentioned 2.5 value only around 2055 to 2065. The DWI will remain higher than the world average for most of the six countries by the end of the century (Heinsohn 2003, 2017a, 2017b). (See Figure 10.) However, significant population growth and increasing life expectancy will exacerbate the risk of conflicts, even after reaching the world average. 
Figure 10

Development of the demographic war index in the main countries of origin of EU's asylum applicants

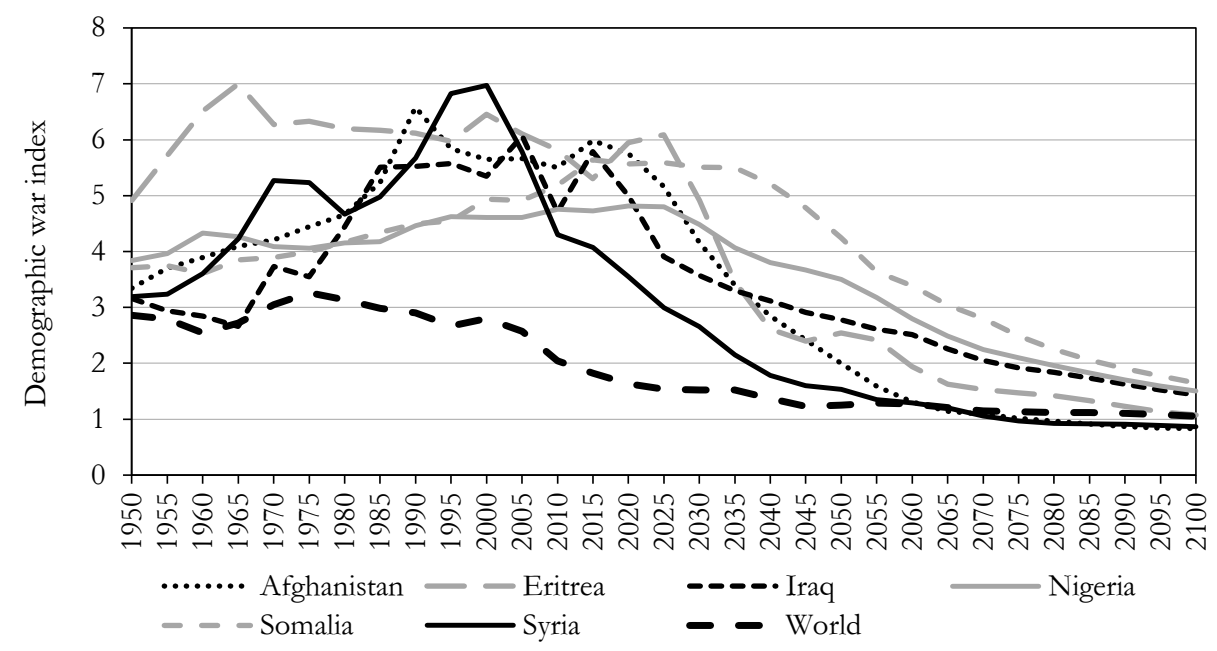

Source: Own calculation based on Heinsohn (2003, 2017a, 2017b) and United Nations data.

To examine relevance of the DWI, hereinafter countries with the highest DWI values and the overall number of refugees, asylum seekers, IDPs, and other people affected by migration from these countries are compared.

Most of these countries with the highest values are in Africa, and 7 of the first 30 countries with more than 1 million inhabitants are affected by forced displacement. Although major refugee-sending countries like Syria and Sudan are not included among those with the highest DWI values (Heinsohn 2003, 2017a, 2017b, UNCHR). (See Figure 11.) Overall, this means that most countries involved in considerable armed conflicts (such as Uganda, Chad, Ethiopia, or Kenya, which host a large South Sudanese, Sudanese or Somali refugee population) are struggling with a demographic problem, and it is likely that their neighbouring countries also have higher risks. These forced migrants compete with the native population for fewer positions in the labour market, which, in major cities, increases the segregation of those unable to find employment.

Regional Statistics, Vol. 8. No. 1. 2018: 29-48; DOI: 10.15196/RS080103 
Figure 11

Countries of origin with the highest demographic war index and their total population affected by migration, 2015

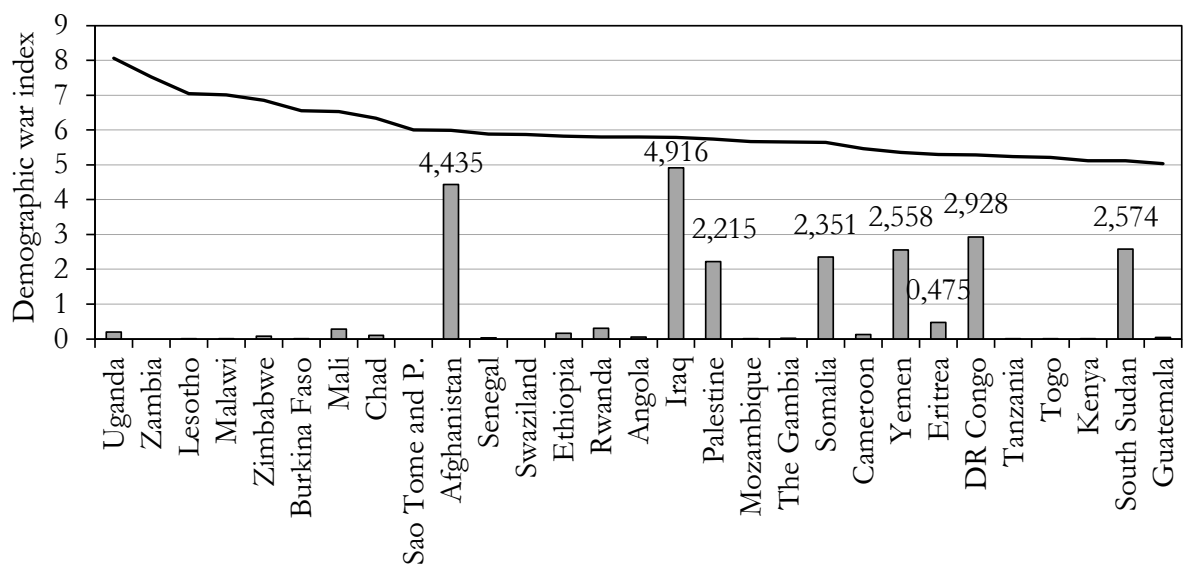

$\square$ Total population (refugees, asylum seekers, IDPs, etc.) affected by migration (million)

Demographic war index

Note: Sao Tome and P. - Sao Tome and Principe; DR Congo - Democratic Republic of Congo.

Source: Own calculation based on Heinsohn (2003, 2017a, 2017b) and UNHCR (2017) data.

Considering all countries with notable ongoing violent military operations ${ }^{5}$, Africa is highly represented. In addition, only slightly more countries have high DWI $(>2.5)$ values than those with low or middle DWI $(<2.5)$ values. At the national level, a continuous conflict-affected region exists from Mali to Myanmar. The only interruption is Iran, suggesting that North, Central, and East Africa, the Middle East as well as South Asia and parts of Southeast Asia are highly affected by violent militant activities and demographic problems. The most peaceful regions are developed countries with shrinking or stable populations such as Europe, North America, most parts of South America and Southeast Asia, Australia, and New Zealand. South Africa and most Western African countries are also relatively peaceful compared to other parts of the continent, although these countries also have a large young population (Heinsohn 2003, 2017a, 2017b, HIIK, UCDP). (See Figure 12.)

\footnotetext{
${ }^{5}$ Considered as at least a level 3 (violent crisis) armed conflict by the Heidelberg Institute for International Conflict Research (HIIK), which has caused combined fatalities of more than 100 people in 2016 according to the Uppsala Conflict Data Program (UCDP).
}

Regional Statistics, Vol. 8. No. 1. 2018: 29-48; DOI: 10.15196/RS080103 
Demographic war index of the countries involved in considerable armed conflicts, 2016

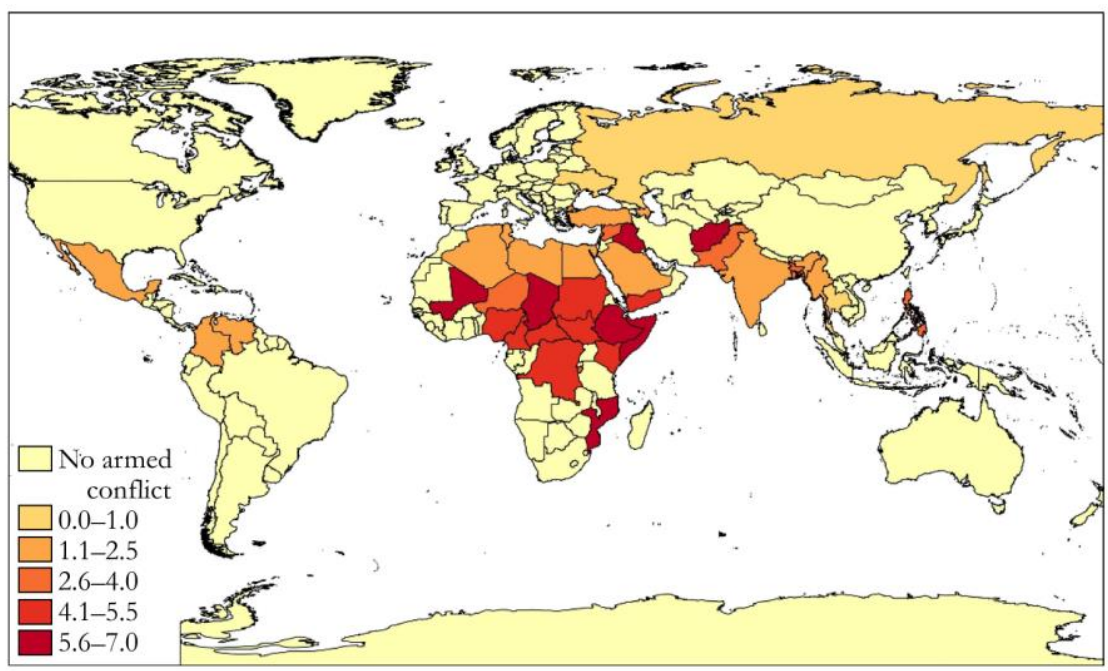

Source: Own elaboration based on Heinsohn (2003, 2017a, 2017b), HIIK and UCDP data.

In general, this does not mean that demographic issues are the only factors causing armed conflicts or population displacement. Eritrea is situated in the middle of this continuous region, as are Djibouti, partially Israel, and Jordan. The case of Eritrea shows that political reasons can cause significant refugee migration. In addition, a stable or shrinking population cannot prevent a nation from being involved in some form of violent militant activity (for example, Russia or Ukraine). This only implies that the risk of a violent conflict is higher in countries where the DWI value is more than 2.5, such as in most parts of Africa. Handling these conflicts appropriately is essential, as they slow demographic transition in the involved countries, deepening complex political and socio-economic crises.

\section{Conclusions}

The integration of recognised refugees and asylum seekers will remain a highly debated issue in international politics in the coming years. These conflict-affected zones are in the most underdeveloped or politically unstable regions, and it is expected that the average literacy rate of these areas is lower than the national average. Thus, the most significant refugee-sending sub-state areas of South Sudan, Afghanistan, Pakistan, Sudan, or Nigeria, for example, are likely to have illiteracy rates higher than $50-60 \%$, the national average of these countries (United Nations). The social inclusion of refugee populations from underdeveloped regions in the highly

Regional Statistics, Vol. 8. No. 1. 2018: 29-48; DOI: 10.15196/RS080103 
developed countries of the EU will take decades, even if there is a clear need for a new labour force in each member state.

Meanwhile, the role of the EU as a destination area for forced migrants is still significant. The increasing number of global refugee and displaced populations, dynamic political changes, armed conflicts in countries of origin, and migratory routes of transit states are causing complex global challenges. Between 2008 and 2016, 4.9 million asylum applications were registered by the EU member states, and new conflict zones were added to the list of countries of origin yearly after the 'Arab Spring'. Following the EU-Turkey agreement in March 2016 and strengthened border control by the Libyan and Italian authorities, these numbers started to stabilise in 2017, but as discussed in this paper, demographic pressure and risk of violent armed conflicts will stay high or increase.

This study aimed to measure the demographic risks of violence and its connection with refugee migration, highlighting a link between armed conflicts and the share of the young (15-19) versus retiring (55-59) male age groups (called the DWI). As such, 7 of the 30 countries with the highest rates also have a forced displaced population totalling more than 1 million people, and other countries hosting millions of refugees like Uganda, Chad, Ethiopia, and Kenya are at a higher risk of involvement in the spill-over effect of neighbouring armed conflicts. This is also due to the demographic facts that TFR will remain higher in these areas than the European average, while increasing life expectancy will retain the DWI values above the critical level of 2.5 in most countries of origin for decades. Therefore, there will be a growing need for new positions in the labour market. This means population growth in all countries of origin, among which Nigeria will house more people than the population of all European countries combined by the end of the century.

The consequences of this demographic pressure cannot be predicted accurately in the decades to come. However, the abovementioned facts compared to the low fertility rates of an ageing Europe highlight the increasing importance of monitoring migration flows and migratory routes to the EU in the 21 st century.

\section{REFERENCES}

ABEL, G. J.-SANDER, N. (2014): Quantifying Global International Migration Flows Science 343 (6178): 1520-1522. https://doi.org/10.1126/science.1248676

Booth, H. (1982): On the Role of Demography in the Study of Post-War Migration to Western Europe European Demographic Information Bulletin 13 (4): 161-171. https://doi.org/10.1007/bf02917610

BORJAS, G. (1989): Economic Theory and International Migration. The International Migration Review 23 (3): 457-485. https://doi.org/10.2307/2546424

Brunborg, H.-TABEAU, E. (2005): Demography of Conflict and Violence: An Emerging Field European Journal of Population/Revue Européenne de Démographie 21 (2/3): 131-144. https://doi.org/10.1007/s10680-005-6850-7

Regional Statistics, Vol. 8. No. 1. 2018: 29-48; DOI: 10.15196/RS080103 
Brunborg, H.-Urdal, H. (2005): The Demography of Conflict and Violence: An Introduction Journal of Peace Research 42 (4): 371-374. https://doi.org/ 10.1177/0022343305054084

Choucri, N. (1974): Population Dynamics and International Violence: Propositions, Insights and Evidence Massachusetts Institute of Technology Center for International Studies, Lexington.

Cincotta, R. P.-Engelman, R.-Anastasion, D. (2003): The Security Demographic: Population and Civil Conflict After the Cold War Population Action International, Washington, DC.

Collier, P.-Hoeffler, A. (1998): On Economic Causes of Civil War Oxford Economic Papers (50): 563-573. https://doi.org/10.1093/oep/50.4.563

Collier, P. (2000): Doing Well Out of War: An Economic Perspective In: Berdal, M.Malone, D. M. (eds.) Greed \& Grievance: Economic Agendas in Civil Wars Lynne Rienner, Boulder.

DEMÉNY, P. (2016): Európa két demográfiai válsága: a látható és a fel nem ismert Kisebbségkutatás 25 (1): 7-19.

EKÉNÉ ZAMÁRDI, I.-DÖvÉNYI, Z. (2010): Migráció és mobilitás In: TÓTH, J. (ed.): Világföldrajz pp. 376-405., Akadémiai Kiadó, Budapest.

Heinsohn, G.-STEIGER, O. (1977): The significance of 'The Wealth of Nations' for an economic theory of the production of population 1). European Demographic Information Bulletin 8 (4): 138-149. https://doi.org/10.1007/bf02917688

Heinsohn, G.-STEIGER, O. (1979a): Jean Bodin, Das 'Universalgenie Der Neuzeit' Oder: Der Wahre Meisterdenker: Neun bevölkerungstheoretische Thesen European Demographic Information Bulletin 10 (3): 97-108. https://doi.org/ 10.1007/bf02917863

Heinsohn, G.-STeiger, O. (1979b): The Economic Theory of Fertility. An Alternative Approach of an Economic Determination Procreation Metroeconomica 31 (3): 271-298. https://doi.org/10.1111/j.1467-999x.1979.tb00249.x

HeINSOHN, G.-STEIGER, O. (1980): Understanding the Rationale behind the Malthusian Theory of Population European Demographic Information Bulletin 11 (2-3): 72-81. https://doi.org/10.1007/bf02917620

Heinsohn, G. (2003): Söhne und Weltmacht - Terror im Aufsteig und Fall der Nationen Orell Füssli Verlag AG, Zürich.

KasakofF, A.-ADAms, I. (1995): The Effect of Migration on Ages at Vital Events: A Critique of Family Reconstitution in Historical Demography European Journal of Population/Revue Européenne de Démographie 11 (3): 199-242. https://doi.org/10.1007/bf01264948

Kelly, C. B. (2000): Demography and International Migration In: BreTtell, C. B.Hollifield, J. F. (eds.) Migration Theory -Talking across Disciplines pp. 43-60., Routledge, London.

KINCSES, Á. (2015): International Migration Diversity in Hungary in the 2011 Population Census Data Regional Statistics 5 (2): 108-124. https://doi.org/ $10.15196 /$ ts 05206

Kocsis, K.-SAnsum MolnÁR, J.-Kreinin, L.-MichalkÓ, G.-BOTTLIK, Zs.-SZABÓ, B.BALIZs, D.-VARGA, GY. (2016): Geographical characteristics of contemporary

Regional Statistics, Vol. 8. No. 1. 2018: 29-48; DOI: 10.15196/RS080103 
international migration in and into Europe Hungarian Geographical Bulletin 65 (4): 369-390. https://doi.org/10.15201/hungeobull.65.4.6

KRALY, E. P.-GNANASEKARAN, K. S. (1987): Efforts to improve international migration statistics: A historical perspective International Migration Review 21 (4): 967-995. https://doi.org/10.2307/2546500

LEE, E. (1966): A theory of migration. Demography 3 (1): 47-57. https://doi.org/10.2307/2060063

Lesthaeghe, R. (2010): The unfolding story of the second demographic transition Population and Development Review 36 (2): 211-251. https://doi.org/10.1111/j.17284457.2010.00328.x

L. RÉDEI, M. (2006): Demográfiai ismeretek Reg-Info Kft., Budapest.

L. RÉDEI, M. (2014): A nemzetközi migráció demográfiai és geográfiai aspektusai In: TARrósy, I.-GLIED, V.-VÖRÖS, Z. (eds.) Migrációs tendenciák napjainkban pp. 29-43., Publikon, Pécs.

NORDÅs, R.-DAVEnPORT, C. (2013): Fight the youth: Youth bulges and state repression American Journal of Political Science 57 (4): 926-940.

N. RÓZSA, E. (2012): Demográfia, migráció, urbanizáció - a globalizáció „politikamentes” folyamatai. Az arab társadalom az „arab tavasz” előestéjén Külügyi Szemle 2012 (1): 72-84.

PAP, N.-REMÉNYI, P. (2017): Re-bordering of the Hungarian South: Geopolitics of the Hungarian border fence Hungarian Geographical Bulletin 66 (3): 235-250. https://doi.org/10.15201/hungeobull.66.3.4

RANDALL, S. (2005): The demographic consequences of conflict, exile and repatriation: A case study of Malian Tuareg. European Journal of Population/Revue Européenne de Démographie 21 (2-3): 291-320. https://doi.org/10.1007/s10680005-6857-0

RAVEnsteIn, E. (1889): The laws of migration. Journal of the Royal Statistical Society 52 (2): 241-305.

Tabutin, D.-Schoumaker, B.-Rogers, G.-Mandelbaum, J.-Dutreuilh, C. (2005): The demography of the Arab world and the Middle East from the 1950s to the 2000s. A survey of changes and a statistical assessment Population 60 (5-6): 505-615. https://doi.org/10.2307/4148186

TAButin, D.-Schoumaker, B. (2004). The demography of Sub-Saharan Africa from the 1950 s to the 2000s. A survey of changes and a statistical assessment Population 59 (3-4): 457-555. https://doi.org/10.2307/3654914

TARRÓSY, I. (2017): Afrikaiak a világban, afrikaiak Magyarországon - elhanyagolt diaszpóra? Modern Geográfía 12 (4): 1-14.

URDAL, H. (2005): People vs. Malthus: Population pressure, environmental degradation, and armed conflict revisited Journal of Peace Research (42): 417-434. https://doi.org/10.1177/0022343305054089

URDAL, H. (2006): A clash of generations? Youth bulges and political violence International Studies Quarterly 50 (3): 607-629. https://doi.org/10.1111/j.14682478.2006.00416.x

Willekens, F. (1994): Monitoring international migration flows in Europe: Towards a statistical data base combining data from different sources European Journal of

Regional Statistics, Vol. 8. No. 1. 2018: 29-48; DOI: 10.15196/RS080103 
Population/Revue Européenne de Démographie $10 \quad$ (1): 1-42. https://doi.org/10.1007/bf01268210

ZolBerg, A. (1989): The next waves: Migration theory for a changing world The International Migration Review 23 (3): 403-430. https://doi.org/10.2307/2546422

\section{INTERNET REFERENCES}

CIA The World Factbook - Median age. https://www.cia.gov/library/publications/theworld-factbook/fields/2177.html (downloaded: 27.12.2017)

EUROSTAT Asylum and managed migration database http://ec.europa.eu/Eurostat/web/ asylum-and-managed-migration/data/database (downloaded: 11.09.2017)

FRONTEX Migratory routes map http://frontex.europa.eu/trends-and-routes/migratoryroutes-map/ (downloaded: 19.12.2017)

Global Migration Data ANALYsis Centre (GMDAC) (2018): Registration and identity management of irregular migrants in the EU. p. 7. http://gmdac.iom.int/gmdacdata-briefing-12 (downloaded: 07/02/2018)

HeINSOHN, G. (2017a): Why a two-state solution doesn't guarantee peace in the Middle East. http://www.washingtonexaminer.com/why-a-two-state-solution-doesntguarantee-peace-in-the-middle-east/article/2615183 (downloaded: 13.09.2017)

Heinsohn, G. (2017b): Demographic War Index 2017: Ranking by Country. https:/ /www.scribd.com/document/339621828/WAR-Index-2017-RankingMap-Heinsohn-06-02-2017 (downloaded: 28.12.2017)

Heidelberg Institute For International CONFlict RESEArCh (HIIK) Daten http://hiik.de/de/daten/ (downloaded: 09.09.2017)

UpPSALA CONFlict DATA PROGRAm (UCDP) http://ucdp.uu.se (downloaded: 18.09.2017)

UNITED NATIONS data portal http://data.un.org/Default.aspx (downloaded: 17.09.2017)

United Nations (2017): The International Migration Report 2017 (Highlights) https://www.un.org/development/desa/publications/international-migrationreport-2017.html (downloaded: 16.10.2017)

United Nations High Commissioner for Refugees (UNHCR) Convention and Protocol Relating to the Status of Refugees. http://www.unhcr.org/3b66c2aa10.pdf (downloaded 10.09.2017)

UNHCR (2017): Global Trends Forced Displacement in 2016. http://www.unhcr.org/ 5943e8a34.pdf (downloaded: 10.12.2017)

Regional Statistics, Vol. 8. No. 1. 2018: 29-48; DOI: 10.15196/RS080103 